\title{
Powojenne problemy społeczno-gospodarcze Lubelszczyzny lat 1944-1945 w świetle sprawozdania Izby Przemysłowo-Handlowej w Lublinie
}

\author{
The post-war socio-economic problems of Lublin region \\ in the years 1944-1945 \\ in the report of the Chamber of Industry and Commerce in Lublin
}

\section{STRESZCZENIE}

Władza komunistyczne w Polsce, posiadając niewielkie poparcie społeczne, musiały w procesie porządkowanie życia społeczno-gospodarczego odwołać się do przedwojennych instytucji i kadr. Izby Przemysłowo-Handlowe w II Rzeczypospolitej stanowiły ogniwo pośredniczące $\mathrm{w}$ kontaktach pomiędzy aparatem państwowym a przedsiębiorcami. W zmienionej rzeczywistości funkcjonowały jako forma organizacyjna prywatnego przemysłu i handlu. Wykorzystano je w zdecydowanej rozprawie z sektorem prywatnym w przemyśle i handlu podczas nacjonalizacji przemysłu, a następnie "bitwy o handel”. Publikowany dokument stanowi przykład raportu periodycznego przygotowanego przez Izbę Przemysłowo-Handlową w Lublinie, zawierającego informacje na temat bardzo ciekawego okresu pierwszego roku po wyparciu Niemców z Lubelszczyzny. Znajduje się tu opis reaktywowania Izby i podporządkowania Polskiemu Komitetowi Wyzwolenia Narodowego. Omówiono w nim zagadnienie zatrudnienia, cen, aprowizacji, wpływu trudności komunikacyjnych na normalizację życia gospodarczego, środków pieniężnych. Drugą część stanowi charakterystyka stanu przemysłu w podziale branżowym, ochrony przed demontażem i wywiezieniem do Niemiec, powojennego chaosu. W ostatniej części dokonano analizy specyfiki handlu na Lubelszczyźnie. Punktem wyjścia są uwagi na temat handlu przedwojennego, wskazanie głównych produktów eksportowych, charakterystyki struktury branżowej i skutków wojny. Pojawia się także wątek blokującej inicjatywę prywatną niepewności i obaw przed wdrażaniem wzorców radzieckich w handlu.

Słowa kluczowe: izba przemysłowo-handlowa, Lubelszczyzna, handel, przemysł 
Przejęcie władzy przez komunistów w Polsce po 1944 r. oznaczało diametralną zmianę porządku politycznego, gospodarczego i społecznego. Pierwsze lata upłynęły pod znakiem ostrej walki o wyeliminowanie przeciwników nowej władzy, ale co równie ważne - likwidacji skutków wojny. Katastrofalne skutki wojny w pewnym sensie ułatwiły władzy realizację własnych celów, ponieważ skrupulatnie wykorzystywano naturalne potrzeby podźwignięcia się $\mathrm{z}$ ruin, poczucia bezpieczeństwa i stabilizacji życiowej, które mogły łagodzić krytyczny stosunek do nowej rzeczywistości. Władza była silną siłą aparatu represji i sojuszniczej Armii Czerwonej, ale posiadając niewielkie poparcie społeczne musiała odwołać się w procesie porządkowanie życia społeczno-gospodarczego do przedwojennych instytucji i kadr.

Jedną z takich instytucji była Izba Przemysłowo-Handlowa. Jej lubelska placówka w 1944 r. miała za sobą już dziesięcioletnie doświadczenie działalności w warunkach Polski niepodległej oraz blisko pięcioletnie w okresie okupacji niemieckiej. Izby miały bardzo szerokie kompetencje i stanowiły ważne ogniwo w systemie urzędów i instytucji realizujących politykę gospodarczą i społeczną państwa. Zostały powołane jako ogniwo pośredniczące $\mathrm{w}$ kontaktach pomiędzy aparatem państwowym a przedsiębiorcami. Jako instytucje samorządu gospodarczego zrzeszały przemysłowców i kupców, blisko współpracowały z władzami, wykonując wyznaczone zadania, aktywnie uczestniczyły w tworzeniu prawa poprzez opiniowanie i delegowanie przedstawicieli do odpowiednich gremiów, organizowały życie środowiska przemysłowo-kupieckiego, urządzając targi, wystawy itp. ${ }^{1}$

Rok 1944 stanowił w historii Izb Przemysłowo-Handlowych moment zwrotny. W zmienionej rzeczywistości, w ścisłym związku z ewolucją (być może bardziej precyzyjne byłoby określenie odkrywaniem kart) polityki gospodarczej władz komunistycznych, traciły one sukcesywnie znaczenie, aż do formalnej likwidacji w latach 1950-1951. Powołane jako forma organizacyjna prywatnego przemysłu i handlu zostały wykorzystane $\mathrm{w}$ zdecydowanej rozprawie $\mathrm{z}$ sektorem prywatnym w przemyśle i handlu podczas nacjonalizacji przemysłu, a następnie "bitwy o handel”. Mimo to Izby były aktywnymi podmiotami życia społeczno-gospodarczego, a przez to, iż zobligowano je do składania periodycznych raportów/analiz

${ }^{1}$ K. Dąbrowski, Zarys historii Izby Przemysłowo-Handlowej w Lublinie w latach 19291951, http://iph.lublin.pl/index.php/historia, [dostęp: 19 czerwca 2015 r.] 
sytuacji gospodarczej, pozostawiły po sobie bardzo interesującą spuściznę archiwalną․

Publikowany poniżej dokument stanowi przykład raportu periodycznego przygotowanego przez Izbę Przemysłowo-Handlową w Lublinie. Oryginał przechowywany jest w Archiwum Państwowym w Lublinie $^{3}$. Dokument zawiera informacje na temat bardzo ciekawego okresu pierwszego roku po wyparciu Niemców z Lubelszczyzny. Pierwszą część dokumentu stanowi opis reaktywowania Izby Przemysłowo-Handlowej i podporządkowania się nowej, popieranej przez Stalina, władzy w postaci Polskiego Komitetu Wyzwolenia Narodowego. Opisany został proces wyboru nowych władz. Jednak najciekawszy wydaje się fragment prezentujący szeroki zakres problemów, którymi Izba zajmowała się w pierwszych miesiącach. Warte podkreślenia jest to, iż autorzy sprawozdania nie pozostawiają badaczom złudzeń, jak mocno niekompletne i nieprecyzyjne są publikowane dane. W dalszej kolejności omówione zostało zagadnienie zatrudnienia, kwestia cen (szczególnie interesująca jest analiza mechanizmów regulacyjnych stosowanych przez państwo) oraz aprowizacji (systemy kartkowe, porównania z okupacją piętrzące się problemy powojenne). Istotnym elementem ówczesnej rzeczywistości było uporządkowanie systemu pieniężnego, co znalazło odzwierciedlenie w źródle. Pod pozorem normalizacji dokonywano drenażu społeczeństwa i przekazywano środki na budowę aparatu władzy. Przedstawiono ceny artykułów państwowych, wpływ trudności komunikacyjnych na normalizację życia gospodarczego, zagadnienie środków pieniężnych. Drugą wyraźnie wyodrębnioną część stanowi charakterystyka stanu przemysłu, który omówiono ze szczegółowym podziałem na kilkanaście branż. Ocena dramatycznej sytuacji w budownictwie skłoniła np. autorów do postulowania rozwoju inicjatywny prywatnej w tej branży. Poruszono problem ochrony przemysłu przed demontażem i wywiezieniem do Niemiec, cech powojennego chaosu, trudności pierwszego okresu. Trzecia, ostatnią część stanowi analiza specyfiki handlu na Lubelszczyźnie. Punktem wyjścia są uwagi na temat handlu przedwojennego, wskazanie głównych produktów eksportowych, charakterystyki struktury branżowej i skutków wojny. Pojawia się także wątek blokującej inicjatywę prywatną niepewności i obaw przed wdrażaniem wzorców radzieckich w handlu.

${ }^{2}$ Idem; Archiwalia izb przemysłowo-handlowych. Stan i perspektywy badań, red. idem, Ryki 2012, s. 28-44; Archiwum Państwowe w Lublinie, Izba Przemysłowo-Handlowa w Lublinie, Inwentarz zespołu.

${ }^{3}$ Archiwum Państwowe w Lublinie, Izba Przemysłowo-Handlowa w Lublinie, sygn. 63, k. 1-41. 
Podczas opracowywania dokumentu dokonano jedynie kosmetycznych zmian związanych z niewielką korektą ortograficzną i interpunkcyjną oraz pominięto spis treści. Zachowana została natomiast $\mathrm{np}$. oryginalna pisownia słowa Niemcy małą litera, co było dosyć charakterystyczne dla tego okresu i określało stosunek do sprawców ogromnej powojennej traumy.

\section{Sprawozdanie z organizacji Izby Przemysłowo-Handlowej w Lublinie i stosunków gospodarczych jej okręgu za czas 22 lipca 1944 r. do 15 czerwca 1945 r.}

ORGANIZACJA IZBY

W momencie oswobodzenia Lublina nie było żadnego z członków dawnego prezydium Izby Przemysłowo-Handlowej, gdyż 2 zginęło, a miejsce pobytu i los pozostałych były nieznane. Cały ciężar ponownej organizacji i reprezentacji tej instytucji spadł na jej dawnego Dyrektora inż. Tadeusza Kryńskiego. On też zgłosił się do przybyłego najpierw do Lublina delegata P[olskiego] K[omitetu] W[yzwolenia] N[arodowego] Ob. Szymona Żołny ${ }^{4}$, oddając mu do dyspozycji aparat Izby i ocalone materiały dotyczące lubelskiego życia gospodarczego, co zostało przyjęte z zupełnym zrozumieniem i należycie wykorzystane. Zaznaczyć tu należy, że tak szybkie umożliwienie uruchomienia biura Izby zawdzięcza się poczuciu obywatelskiemu dawnych pracowników, którzy z narażeniem swej osobistej wolności i życia w okresie likwidacji okupacji i ewakuowania się niemców, wynosili z biura maszyny do pisania i liczenia oraz podstawę dokumentacji - kartotekę przemysłową i handlową. Materiały i pomoce biurowe były przechowywane w prywatnym mieszkaniu Dyrektora Izby, z chwilą wejścia władz 2 maszyny i trochę mebli oddane zostało władzom wojskowym i cywilnym w użytkowanie.

Po zorganizowaniu się PKWN w Lublinie kontakty Izby z resortami rządowymi, a w szczególności z resortem Gospodarki i Finansów i jego kierownikiem Min. [Janem Stefanem] Hanemanem były nadal bardzo ożywione. Izba dostarczała przede wszystkim wszelkich danych odnośnie przemysłu i wspólnie badano potrzeby przemysłu w zakresie surowców i materiałów pędnych, poza tym zaś Izba dzięki ukrytej przez pracowników w piwnicy i ocalonej od zniszczenia bibliotece, dopomagała

${ }^{4}$ Jan Manugiewicz „Szymon Żołna”, etnograf, przed wojną dyrektor Muzeum Etnograficznego w Łodzi. 
wszystkim prawie resortom a także wojsku w pracach dokumentacyjnych i organizacyjnych.

W myśl wytycznych uzgodnionych z Resortem Gospodarki Narodowej i Finansów, Dyrektor Izby zwołał na dzień 5 września 1944 [r.] wszystkich dawnych radców Izby w liczbie 13, a także przedstawicieli przemysłu i Zarządu Stowarzyszenia Kupców Polskich. Zebrani ukonstytuowali się jako Tymczasowa Rada Izby i wyłonili Zarząd - składający się z 2 przedstawicieli przemysłu, 2 przedstawicieli handlu i 1 przedstawiciela bankowości, upoważniając ten Zarząd do kooptowania dalszych radców. W tej drodze skompletowana Izba odbyła w dniu 21 listopada 1944 r. w obecności przedstawiciela Kierownika Resortu Gospodarki Narodowej i Finansów, swe zebranie plenarne.

Prezydium Izby przedstawia się następująco:

Prezes: Roman Petschl

v[ice]prezesi z sekcji przemysłowej: Edward Krausse inż. Roman Laśkiewicz

v[ice]prezesi z sekcji handlowej: Karol Freyberg Wojciech Zwoliński

W związku z powołaniem do życia Izby Przemysłowo-handlowej w Rzeszowie i pracami przygotowawczymi nad zorganizowaniem Izb w Warszawie (na Pradze) i Białymstoku, specjalnym pismem [Resortu] Gospodarki Narodowej i Finansów powierzono Izbie obowiązki Izby urzędującej Związku Izb, co Izba pełniła do dnia 13 marca 1945 r.

Izba odbyła dotychczas 4 plenarne posiedzenia, omawiając na nich bieżące zagadnienia gospodarcze. Poza tym wyłoniono 5 komisji a mianowicie: polityki przemysłowej, skarbowo-podatkowa, szkolnictwa zawodowego, polityki socjalnej i polityki handlowej, tudzież jedną podkomisję - dla przedsiębiorstw prowadzonych w większym rozmiarze.

Biuro Izby, liczące przed wojną 35 osób, obecnie liczy 19 pracowników umysłowych i fizycznych. Prace biura w okresie organizacyjnym [szły] w kierunku uporządkowania tak potrzebnej dla należytej orientacji w terenie kartoteki przedsiębiorstw. Izbowa kartoteka przemysłowa dla miasta Lublina jest już skompletowana i co ważniejsze niemal w 100\% zaktualizowana, tak że daje dokładny obraz lubelskich przedsiębiorstw, ich rozmiaru, obrotów, produkcji itd. Dane z prowincji a także dane co do handlu są już ujęte o ile chodzi o wykazy ilościowe i nazwiskowe, z uwagi jednak na trudności komunikacyjne aktualizacja posiadanych danych jest w toku.

W zakresie promieniowania organizacyjnej działalności Izby, wspomnieć należy powstanie na skutek jej inicjatywy na podstawie art. 69 prawa przemysłowego szeregu zrzeszeń branżowych (zrzeszeń przemysło- 
wych), a mianowicie Zrzeszenia Przedsiębiorców Przemysłu Metalowego, Właścicieli Drukarń, Przemysłu Ceramicznego, Budowlanego i Wytwórni Wód Gazowych, które pod egida Izby rozwijają stałą aktywność. Kontakt, a raczej ścisła współpraca ze Stowarzyszeniem Kupców Polskich i jego prowincjonalnymi oddziałami jest również stale utrzymywana.

Realizując Zalecenie Ministra Aprowizacji i Handlu ze stycznia b.r. Izba w wyżej wymienionej współpracy ze zrzeszeniami kupieckimi prowadzi akcję regulacji cen $\mathrm{w}$ drodze notowania cen na wolnym rynku dla 11 branż. Notowane ceny są $\mathrm{w}$ myśl otrzymanych dyrektyw periodycznie przesyłane władzom centralnym. Urząd Walki z Lichwą jest również w stałym kontakcie z Izba, która mu dostarcza lub opiniuje materiały kalkulacyjne.

Co się tyczy pozostałych ustawowo zakreślonych ram swej działalności to Izba opiniowała na wezwanie władz szereg projektów dekretów (m.in. projekt dekretu o 50\% dodatku wojennego do państwowego podatku dochodowego, o nadzwyczajnym podatku od wzbogacenia wojennego i kartach przemysłowo-podatkowych, o Radach Załogowych itp.), a także z własnej inicjatywy składała uwagi w sprawach dekretów i zarządzeń (np. o reformie walutowej). Dalej zgłaszała kandydatów do Rady Ubezpieczalni Społecznej, na ławników Sądów Pracy, członków Komisji Odwoławczych przy Izbie Skarbowej, zestawiła listę biegłych dla władz skarbowych, aktualizując jednocześnie listę biegłych zaprzysiężonych przy Izbie (przy czym zaprzysiężono 16 księgowych), delegowała przedstawicieli do Komisji Szacunkowej majątku poniemieckiego, komisji czynszów za lokale Komisji przydziału lokali użytkowych itp.

W zakresie szkolnictwa zawodowego wznowiono rejestrowanie uczniów w przemyśle, a także obecnie rejestrowani są uczniowie w handlu. W roku ubiegłym Izba wraz z przedstawicielem Resortu Gospodarki Narodowej i Finansów odbyła szereg konferencji z organizacjami kupieckimi - $\mathrm{w}$ rezultacie których przyśpieszono uruchomienie 2 szkół handlowych w Lublinie, oraz prywatnych szkół handlowych w Białej Podlaskiej, Chełmie, Krasnymstawie i Kraśniku. Prócz tego zostały zorganizowane kursy handlowe branżowe 3, 4 i 6-cio miesięczne i nawiązano kontakt w sprawie dokształcania uczniów przemysłowych z odpowiednimi wydziałami Kuratorium. Ostatnio Kuratorium zaprosiło Izbę na zebranie w związku z reformą szkolnictwa zawodowego.

Wspominając ogólnie o szeregu informacji, danych cyfrowych i wykazów, opracowanych przez Izbę na żądanie władz, wspomnieć należy o danych zebranych w drodze specjalnej ankiety i badań na skutek zwrócenia się Komitetu Ekonomicznego, a charakteryzujących potrzeby kapitału obrotowego dla poszczególnych typowych zakładów przemysłowych. 
Dla całokształtu obrazu działania Izby dodać wreszcie należy udzielenie informacji co do eksportu i importu z terenu Polski w czasach przedwojennych przedstawicielom sowieckiego Ministerstwa Przemysłu i Handlu pp. Inoziemcowowi i Miedincewowi, którzy kilkakrotnie odwiedzili Izbę.

Kończąc organizacyjną część sprawozdania, Izba zaznaczyć musi, że na tutejszym terenie spotkała się ze zrozumieniem jej ustawowych zadań - i w swej współpracy z władzami i działalności, mającej na celu odbudowę normalnego biegu życia gospodarczego, mogła rozwijać bez przeszkód uzgodnioną z czynnikami miarodajnymi aktywność.

II. SPRAWOZDANIE GOSPODARCZE ZE STANU OKRĘGU IZBY LUBELSKIEJ

\section{Uwagi wstępne}

Sprawozdanie niniejsze nie może być oceniane w skali przedwojennych sprawozdań Izby, które ukazywały się zazwyczaj w 6 do 8 miesięcy po upływie roku sprawozdawczego i oparte były na wyczerpującym i sprawdzonym materiale dokumentacyjnym i cyfrowym. Jest to właściwie ogólna ocena sytuacji gospodarczej w chwili pisania niniejszych uwag, niejako fotografia migawkowa okręgu Izby, robiona z ogromnej odległości. Zasadniczą bowiem trudnością w pracy nie tylko Izby, ale wszystkich władz i urzędów są trudności komunikacyjne zarówno o ile idzie o kolej czy samochód, jak i pocztę, telegraf i telefon. Poza tym wobec zniszczenia przez okupanta lub działania wojenne wszystkich niemal archiwów, kartotek, statystyk i bibliotek - każdą informację, cyfrę czy wiadomość trzeba zdobywać niemal od początku w drodze żmudnych badań, względnie posługiwać się metodą szacunkową, opartą na wypowiedziach rzeczoznawców danego przedmiotu. Uwaga powyższa porusza wprawdzie rzeczy ogólnie teraz znane, ponieważ jednak każde sprawozdanie gospodarcze Izby jest pewnego rodzaju dokumentem i może i niniejsze sprawozdanie będzie wykorzystywane za kilka lat, konieczne było powyższe stwierdzenie stanu faktycznego w momencie opracowywania sprawozdania. Trudności te, nie podlegające wątpliwości, dały się bardzo we znaki wszystkim władzom centralnym za ich pobytu w Lublinie.

\section{Zagadnienie zatrudnienia}

Najważniejszym momentem $\mathrm{w}$ okresie przejściowym, w pierwszych miesiącach po wypędzeniu niemców, było zagadnienie uniknięcia bezrobocia, zagadnienie zatrudnienia całej rzeszy zarówno stałych mieszkań- 
ców jak i uchodźców, którzy ze wszystkich stron napłynęli do Lubelszczyzny.

Zagadnienie powyższe ilustrują trzy tablice, opracowane na podstawie materiałów Ubezpieczalni Społecznej w Lublinie, a zawierające porównanie cyfr za pierwszy trymestr lat 1939, 1943, 1945, czyli dane przedwojenne, za okupacji i po uwolnieniu od niemców. Dla porządku zaznaczyć należy, że okręg Ubezpieczalni Lubelskiej jest nieco mniejszy niż okręg Izby, gdyż nie obejmuje całego Województwa Lubelskiego, lecz miasto Lublin i powiaty: Lubartów, Włodawa, Chełm, Puławy i Kraśnik. Izba traktuje powyższe cyfry nie jako ścisłe dane statystyczne, lecz jako wskaźniki i podstawę do wniosków i uwag, wobec czego różnica terytorialna nie ma tu znaczenia.

Rok 1939

\begin{tabular}{|c|c|c|c|c|c|c|c|}
\hline \multirow[b]{2}{*}{ Mies[iąc] } & \multicolumn{2}{|c|}{ M[iasto] Lublin } & \multicolumn{2}{|c|}{ Woj. Lubelsk[ie] } & \multicolumn{2}{|c|}{ Razem } & \multirow{2}{*}{$\begin{array}{l}\text { Razem } \\
\text { zatrudnionych }\end{array}$} \\
\hline & $\begin{array}{c}\text { Rob[otni- } \\
\text { ków] }\end{array}$ & $\begin{array}{l}\text { Um[ysło- } \\
\text { wych] }\end{array}$ & $\begin{array}{l}\text { Rob[otni- } \\
\text { ków] }\end{array}$ & $\begin{array}{c}\text { Um[ysło- } \\
\text { wych] }\end{array}$ & $\begin{array}{l}\text { Rob[ot- } \\
\text { ników] }\end{array}$ & $\begin{array}{c}\text { Um[ysło- } \\
\text { wych] }\end{array}$ & \\
\hline I & 15644 & 5053 & 14668 & 2139 & 30332 & 7792 & 38104 \\
\hline II & 15617 & 5150 & 15934 & 2781 & 31551 & 7931 & 39482 \\
\hline III & 16973 & 5149 & 18108 & 2841 & 35081 & 7990 & 43071 \\
\hline IV & 20630 & 5167 & 21219 & 2867 & 41849 & 8034 & 49883 \\
\hline
\end{tabular}

Jak z powyższych cyfr wynika - zakończenie kampanii cukrowniczej nie odbijało się przed wojną na stanie zatrudnienia, gdyż jednocześnie rozpoczynał się sezon budowlany i przemysł budowlany poszukiwał i przyjmował pracowników sezonowych.

Rok 1943

\begin{tabular}{|c|c|c|c|}
\hline Mies[iąc] & Robotników & Umysłowych & $\begin{array}{c}\text { Razem } \\
\text { zatrudnionych }\end{array}$ \\
\hline I & 56604 & 20466 & 77070 \\
\hline II & 58556 & 20819 & 79375 \\
\hline III & 58398 & 20881 & 79279 \\
\hline IV & 58925 & 21088 & 80013 \\
\hline
\end{tabular}


Cyfry z okresu okupacji, nie dające podziału na miasto i resztę Województwa, są podane raczej ze względów historycznych. Trzykrotny niemal wzrost rzekomego zatrudnienia pracowników umysłowych - to skutki obrony przed „łapankami” i wywiezieniem do Rzeszy, to w dużej części fikcyjne zameldowanie $\mathrm{w}$ urzędzie pracy i Ubezpieczalni młodzieży w wieku szkolnym, kobiet, prowadzących w rzeczywistości gospodarstwo domowe swych rodzin itp. Powyższa uwaga w pewnej części stosuje się również do cyfry robotników, poza tym wzrost cyfry zatrudnienia robotników o przeciętnie c/a $60 \%$ wywołany był masowymi robotami budowlanymi, prowadzonymi przez firmy niemieckie, jak np. budowa baraków itp. Wreszcie dla zupełnej ścisłości dodać należy, że w okresie okupacji okręg Ubezpieczalni Lubelskiej obejmował również powiaty: Radzyń, Biała Podlaska i Łuków i trzy gminy Ubezpieczalni Tarnobrzeskiej.

Rok 1945

\begin{tabular}{|c|c|c|c|c|c|c|c|}
\hline \multirow[b]{2}{*}{ Mies[iąc] } & \multicolumn{2}{|c|}{$\mathrm{M}$ [iasto] Lublin } & \multicolumn{2}{|c|}{ Woj. Lubelskie } & \multicolumn{2}{|c|}{ Razem } & \multirow{2}{*}{$\begin{array}{c}\text { Razem } \\
\text { zatrudnio- } \\
\text { nych }\end{array}$} \\
\hline & $\begin{array}{l}\text { Rob[otni- } \\
\text { ków] }\end{array}$ & $\begin{array}{c}\text { Um[ysło- } \\
\text { wych] }\end{array}$ & $\begin{array}{c}\text { Rob[otni- } \\
\text { ków] }\end{array}$ & $\begin{array}{c}\text { Um[ysło- } \\
\text { wych] }\end{array}$ & $\begin{array}{l}\text { Rob[otni- } \\
\text { ków] }\end{array}$ & $\begin{array}{c}\text { Um[ysło- } \\
\text { wych] }\end{array}$ & \\
\hline I & 15841 & 6841 & 10290 & 4006 & 26131 & 10847 & 36978 \\
\hline II & 15499 & 6792 & 12692 & 4491 & 28191 & 11283 & 39474 \\
\hline III & 15353 & 6975 & 11842 & 3874 & 27195 & 10849 & 38044 \\
\hline IV & 15267 & 6602 & 10575 & 3655 & 25842 & 10257 & 36099 \\
\hline
\end{tabular}

Rzut oka na powyższe cyfry pozwala stwierdzić, że już w okresie normowania się warunków na rynku zatrudnienie w cyfrach ogólnych zbliża się do zatrudnienia przedwojennego. Mimo że, jak wspomniano na wstępie omawiania zagadnienia zatrudnienia, na terenie Lubelszczyzny jest wiele ludności napływowej - przerost ten jest nie tylko wyrównany, a nawet przekroczony przez ubytek, wywołany tym, że nie wszyscy wywiezieni do Niemiec czy znajdujący się w obozach już powrócili - jak również służbą wojskową. Na ogół więc stan rynku zatrudnienia uznać można w obecnych powojennych warunkach raczej za pomyślny.

Z bliższej analizy cyfr za rok 1945 wynikają jeszcze dwie obserwacje. Pierwsza to stwierdzenie tendencji do pewnego spadku zatrudnienia w ciągu roku 1945, zjawisko to wywołane jest ukończeniem kampanii cukrowniczej i nie rozpoczęciem dotychczas żadnych niemal prac budowlanych, co, należy mieć nadzieję, będzie zjawiskiem przejściowym. Druga 
- to wzrost ilości pracowników umysłowych, wpłynęło na to scentralizowanie w Lublinie przez dłuższy okres czasu władzy i urzędów państwowych, reforma rolna, a także pauperyzacja pewnych wolnych zawodów (np. adwokaci, inżynierowie), których przedstawiciele ciążą obecnie również do pracy za stałym wynagrodzeniem. Jednakże, jak wszelkie zresztą cyfry niniejszego sprawozdania, ilustrujące tylko pewien moment gospodarczy i koniunkturalny, tak i powyższe dane o zatrudnieniu nie powinny stanowić podstawy do wyciągania zbyt daleko idących wniosków.

\section{Ceny i ich ewolucja}

Jeden z najważniejszych wykładników koniunktury, jakim są ceny, przechodziły tak wielkie ewolucje, że również mogą one być raczej zanotowane dla celów historii gospodarczej. Zniszczenia wojenne, straty, poniesione przez ludność, w połączeniu z dużymi zasobami gotówki, posiadanymi zwłaszcza przez wieś po okresie okupacji - spowodowały w ostatnich miesiącach roku 1944 ogromne wyśrubowanie cen. Mimo przeładowania sklepów komisowych, ceny towarów mało używanych lub nowych osiągały ogromny poziom. Np.: garnitur męski 24000 zł, męskie półbuciki 8000 zł, zegarek niklowy 4000 - do 8000 zł, para pończoch damskich do 2500, męskich 1200, koszula męska 3000 - do 4000 zł. Wyśrubowanie cen dotyczy zresztą wszystkich niemal artykułów np. proszek „kogutek” kosztował 25 zł, zastrzyk „Betabionu” 150 zł itd. Przesunięcie się frontu, większa podaż towarów na rynek i zaspokojenie najpilniejszych potrzeb, a w pewnym względzie i reforma walutowa, wpłynęły na znaczną obniżkę cen. Jeżeli chodzi o wyżej wymienione artykuły, to ceny kształtują się następująco: garnitur męski 4000 - do 6000 zł (zamiast 24000 zł) półbuciki męskie 4000 zł (zamiast 8000 zł), półbuciki męskie pochodzenia kartkowego nieużywane około $900 \mathrm{zl}$, pantofle damskie 4000- do $6000 \mathrm{zl}$, pończochy damskie 250 - do 900 zł. Tym niemniej są to ceny, które dla szerokich rzesz ludności pracującej czynią nadal jakikolwiek zakup z ich bieżących zarobków niemożliwy.

O ile chodzi o artykuły żywnościowe, to skoki cen nie były może tak jaskrawe, w każdym razie jednak na rynku zarysował się spadek cen żywności, co ilustruje tablica pomieszczona na stronie 11. Ceny żywności na wolnym rynku były przedmiotem specjalnego interwencjonizmu władz państwowych i komunalnych, co poważnie zaważyło na ich spadku. Interwencjonizm ten szedł w dwóch kierunkach: nacisku administracyjnego i aprowizacji kartkowej.

Nacisk administracyjny prowadzony był $\mathrm{w}$ drodze bezpośrednich rozmów czynnika urzędowego z kupiectwem, interwencji i kontroli 


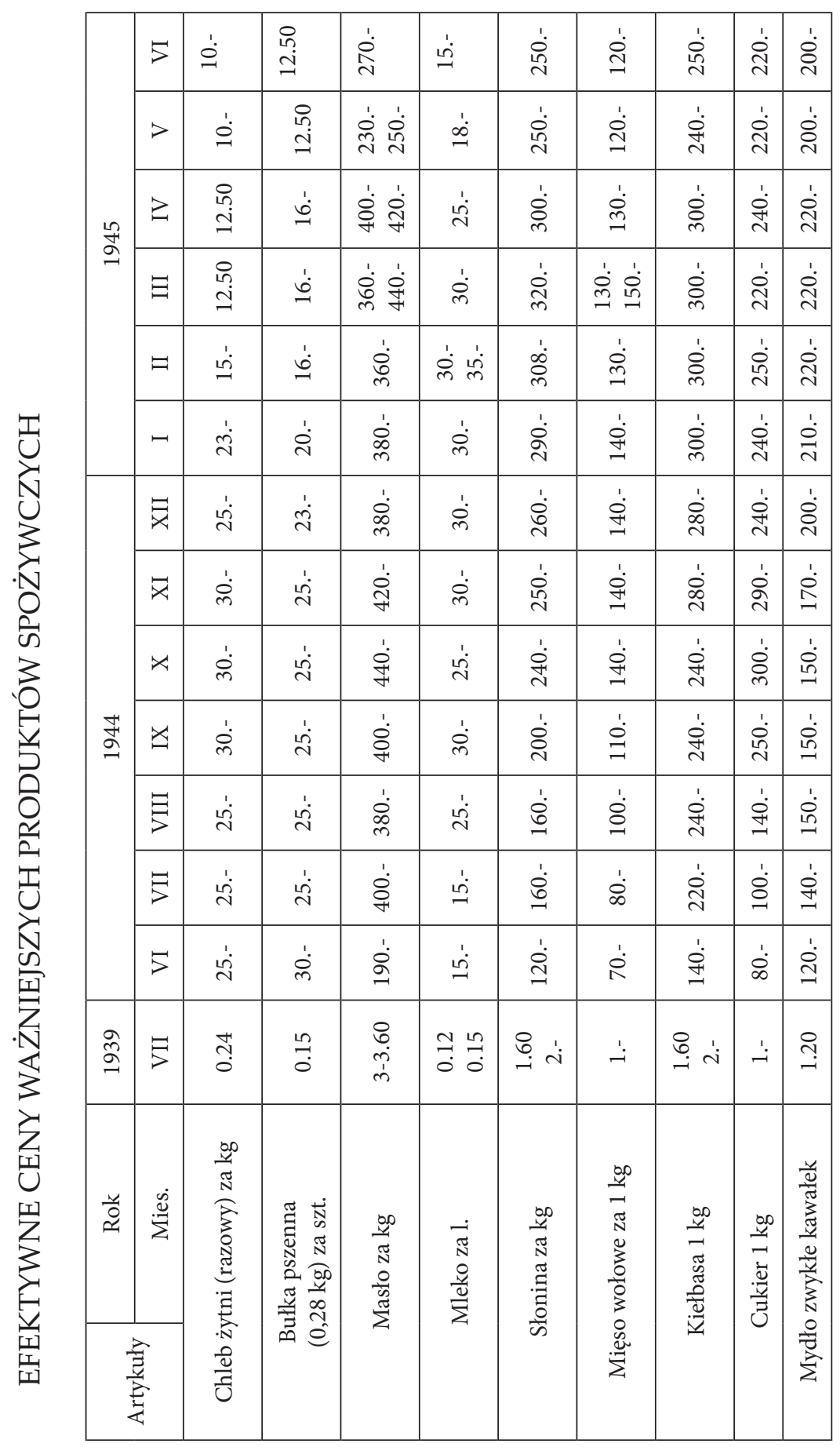


władz wykonawczych jak i przekazanej Izbie Przemysłowo-Handlowej akcji notowania cen, podawanych do wiadomości ogółu konsumentów i kupców przy pomocy wydawanych cenników, w drodze działalności Urzędu do Walki z Lichwą i wreszcie w drodze pomieszczania artykułów w prasie. W skutkach tej nieraz bezwzględnie i tendencyjnie prowadzonej akcji osiągnięto pewne niewątpliwie pomyślne dla konsumenta rezultaty, co się zaś tyczy jednak interwencjonizmu w drodze aprowizacji kartkowej, to ten środek niemal całkowicie zawiódł.

\section{Aprowizacja kartkowa}

W okresie okupacji aprowizacja kartkowa, zorganizowana przez Zarząd Miejski, działała bez zarzutu, mając wybitny charakter powszechności, z tym, że dla ciężej pracujących istniały jeszcze dodatki. Wprowadzona po wypędzeniu niemców gospodarka kartkowa nie skorzystała z doświadczeń okresu okupacji ani o ile chodziło o zasady podziału - ani odnośnie techniki rozdziałowej. Przede wszystkim aprowizacja kartkowa straciła swój powszechny charakter przez fakt utworzenia szeregu grup pracowniczych rozmaicie aprowizowanych - przy jednoczesnym pozbawieniu osób niepracujących prawa do podziału. Wskutek tego liczne rzesze uchodźców i wysiedlonych miały do wyboru albo niewystarczająco zorganizowaną dobroczynność publiczną w Polskim Czerwonym Krzyżu /działalność efektywna - poza zbieraniem składek - wszelkich pomocy dla Warszawy czy ofiar wojny usuwała się z pod kontroli społecznej i była nieuchwytna/ - albo wyprzedawanie się z posiadanej ostatniej garderoby dla uzyskania stosunkowo za poważnych zapasów gotówki, zużywanej $\mathrm{w}$ celu zakupu chleba, na wolnym rynku po zł 60 - za bochenek $2 \mathrm{~kg}$. Jednocześnie technika przydziałowa szwankowała coraz więcej. Zniesiono istniejący podczas okupacji system sklepów obwodowych tj. przydziałowych, gdzie należało rejestrować swe karty i gdzie miało się gwarancję otrzymania przydziału. Wprowadzony zamiast tego system możności zakupu w każdym sklepie przy niedostatecznej dostawie 15-20 bochenków zmuszał do pogoni po sklepach za chlebem i wystawania nie w jednym, ale często wobec wyprzedania chleba w kilku „ogonkach” - co dla świata pracy było bardzo uciążliwe. Jednocześnie zaś plac targowy zarzucony był chlebem kartkowym - jednak nie w cenie 1 zł za kg lecz zł 30 za $\mathrm{kg}$. Z tym stanem rzeczy władze administracyjne absolutnie nie umiały sobie dać rady, bardzo zaś reklamowana pomoc aparatu rozdzielnictwa spółdzielczości ograniczała się do załatwiania sprawy na papierze i utykała wobec piętrzących się trudności. Na szczęście wyniki koniunkturalne (podaż mąki, pora roku, dowóz opału, odpływ uchodźców itp.) oraz na- 
cisk władz administracyjnych spowodowały zniżkę cen chleba w wolnym handlu do 9 zł za kg (zł 18 za bochenek) wobec czego ostrość zagadnienia uległa znacznemu stępieniu.

W rezultacie dalszych, idących po linii uprzywilejowania poszczególnych grup świata pracy, posunięć aprowizacja kartkowa obejmuje dziś tylko pracowników państwowych i samorządowych i ich rodziny względnie pracowników zakładów pracy pracujących wyłącznie dla Państwa; reszta ludności z kart nie korzysta. W ten sposób aprowizacja kartkowa stała się więc niejako częścią wynagrodzenia funkcjonariusza państwowego w szerokim tego słowa rozumieniu - co bynajmniej nie oznacza jeszcze, by i drobna część świata pracy miała jakieś efektywne korzyści z kart - poza chlebem. W ubiegłym roku oprócz chleba wydano 2 pudełka zapałek, $5 \mathrm{dkg}$ drożdży, $15 \mathrm{dkg}$ proszku do prania i 0,5 $\mathrm{kg}$ - marmolady. Cukier wydano po raz ostatni w miesiącu kwietniu rb. (0,5 kg dla urzędników 0,25 kg - dla członków rodzin), mięso w końcu roku ubiegłego, olej i jajka - w lutym rb. Przydział herbaty (po $5 \mathrm{dkg}$ ) nie wystarczył dla wszystkich posiadaczy kart. Jak z tego wynika kartki na tut. terenie nie mają już absolutnie żadnego znaczenia, zwłaszcza przy rozpiętości pobieranych obecnie cen chleba: na kartki 3 zł za kg w [w]olnym handlu 9 zł za $1 \mathrm{~kg}$.

Komunikując powyższe uwagi Izba podkreśla, że docenia $\mathrm{w}$ zupełności trudności, na jakie natrafiły resorty aprowizacyjne, zwłaszcza w zakresie transportu. Tylko bardzo sprężystą ręką trzymana organizacja terenowa może zapewnić sprawne funkcjonowanie aparatu aprowizacyjnego. Świeży i niedoświadczony aparat biurokratyczny, który obawia się odpowiedzialności i przekroczenia przepisów, zdobędzie się chyba tylko w wyjątkowych wypadkach na okazanie inicjatywy, tak koniecznej, o ile w warunkach dzisiejszych trudności chce się osiągnąć konkretne rezultaty. O ile się doda do tego niewystarczające w stosunku do cen rynkowych wynagrodzenie personelu i powszechny zanik przestrzegania zasad moralnych, osiągnięte, a właściwie nieosiągnięte rezultaty nie są rzeczą nieoczekiwaną.

Powyższe uwagi odnoszą się w znacznym stopniu i do innych form zaopatrzenia przydziałowego; jest to pewnego rodzaju „magia przydziałowa" dostępna tylko dla jednostek, z którą nawet sprężyste Związki Zawodowe nie mogą sobie poradzić. Ostatnio np. przy przydziałach materiałów na suknie (po 14 zł za $1 \mathrm{~m}$ ) pracownicy odnośnego działu informowali, że właśnie składy zostały okradzione - i że należy się zgłaszać za pewien czas. Analogiczną informację udzielono przed miesiącem jeżeli chodzi o przydziały obuwia.

Izba ogranicza się do podania znanych jej faktów - bez komentarzy i daleka jest od wyciągania jakichś wniosków - poza stwierdzeniem złej 
organizacji i fatalnej opinii, jakie ona, zarówno jak kradzieże i rekwizycje, wywołują wśród ogółu ludności. Dalsza podaż towarów na rynek wpływa na zaopatrzenie ludności, toteż przydziały kartkowe wszelkiego rodzaju towarów traktujemy jako zjawisko przejściowe. Gdyby jednak system przydziałowy, zwłaszcza w zakresie przydziałów towarów, miał być nadal rozbudowany - to należałoby zagadnienie to poddać rewizji. Trzeba pamiętać, że prowadzony w czasie okupacji rozdział towarów przy pomocy polskiego aparatu kupieckiego aczkolwiek w pewnych przypadkach uległ słusznej krytyce na ogół dawał dobre wyniki. Kupiec dba o swój towar i zdał dobrze egzamin czego dowodem jest, że po ostatnich działaniach wojennych, gdy wszelkie składy należące do władz i urzędów zostały rozgrabione, kupcy na ogół ocalili swoje zapasy materiałów rozdzielczych i oddali je do dyspozycji centralnych władz państwowych. Nowy system rozdziału ze składów, należących do władz, nie dał jak wspomniano dobrych wyników, toteż $\mathrm{w}$ razie utrzymania na czas przejściowy systemu kartek towarowych i dwojakich cen celowe byłoby przestudiowanie zagadnienia pod kątem powrotu do rozdziału przez aparat kupiecki i sklepy rozdzielcze.

\section{Reforma walutowa}

Wspominając o interwencjonizmie Państwa w dziedzinę cen nie można pominąć przeprowadzonej w styczniu rb. wymiany banknotów tzw. krakowskich na banknoty Narodowego Banku Polskiego, co według zamierzeń rządowych miało być również m.in. i środkiem na obniżenie cen. Że bardzo trafnie pomyślane zarządzenie nie wywołało $\mathrm{w}$ terenie przewidzianego efektu - przypisać należy nie dyspozycjom władz centralnych, lecz niewłaściwemu i niemającemu należytego doświadczenia i poziomu aparatowi wykonawczemu. Zrozumiałe jest, że każde zarządzenie deflacyjne musi w pewnym stopniu kogoś dotknąć, nie przypuszczamy jednak, by zamiarem ustawodawcy było uderzenie w pierwszej linii w wieś, a następnie w osiadły i uczciwy handel i przemysł. W samym mieście Lublinie o reformie walutowej mówiło się od listopada r. ub., co wywołało nawet kilkakrotnie popłoch na rynku, odmowę przyjmowania banknotów krakowskich i nawet pewne agio na banknoty Banku Narodowego, dochodzące w pewnych okresach do 8 a nawet do 12 procent. Spekulacje tę uprawiali m.in. repatrianci Żydzi, niemający stałych przedsiębiorstw i działający dosłownie na rynkach i ulicach. Jest publiczną tajemnica, że spekulanci, którzy zgromadzili dawne banknoty, znaleźli w momencie wymiany odpowiednie argumenty dla przekonania o konieczności wy- 
mienienia im posiadanych zapasów przez nieodpowiedzialne elementy wśród nowych i niewypróbowanych pracowników, którzy wkradli się $\mathrm{w}$ szeregi funkcjonariuszy państwowych w momencie tworzenia kadr administracji. Spraw[a] ta zresztą była obszernie poruszana $\mathrm{w}$ czasie zjazdu Stronnictwa Ludowego i podajemy ją tu fragmentarycznie dla podkreślenia dalszych przesłanek. Na terenie Lubelszczyzny obowiązywało wprawdzie zarządzenie Ministra Skarbu, że wkłady bankowe były wymienione w całości, do ostatniej chwili jednak decyzja w tym względzie nie była znana i wielu kupców na podstawie krążących pogłosek w przeddzień wymiany odebrało swe wkłady. Poza tym kupcy na ogół nie uzyskali wymiany swych dziwnych utargów tj. niejako kapitału obrotowego. Dotyczy to również przemysłu. W rezultacie ucieczki od pieniądza w okresie poprzedzającym wymianę - ceny były bardzo wyśrubowane, toteż zapasy towaru w sklepach, ale odświeżane wobec trudności zakupu i transportu, bardzo się zmniejszyły. Po zakończeniu akcji walutowej wytworzyła się taka sytuacja, że przeciętny konsument nie miał pieniędzy, ale kupiec nie miał ani towaru ani gotówki na jego odkupienie. $W$ rezultacie zamiast zniżki cen zapanowała stagnacja. $Z$ drugiej strony anonimowi spekulanci nadal obracali znacznymi zapasami gotówki, którymi starali się opanować dostawę nowych towarów względnie wykupywać wyroby przemysłowe nadal za wszelka cenę. Posunięcie się naprzód Armii Czerwonej i przeniknięcie na rynek towarów, zakupywanych na dłużej przez niemców okupowanych terenach - po o wiele niższych cenach - zakończyło wytworzoną sytuację i ekonomiczne prawo podaży i popytu zaważyło na obserwowanej pewnej tendencji do unormowania się rynku handlowego.

Jedyną dziedzina, na którą na tutejszym terenie reforma walutowa poważnie wpłynęła - był kurs dolarów na tak zw. „,czarnej giełdzie”. O ile około nowego roku dolar papierowy dochodził do 480 zł, a za 20 dolarów w złocie płacono 36000 zł, to po złamaniu się kursu, wywołanym rzucaniem na rynek przez chłopów i ludność miejską pozbawioną środków obiegowych, lokat w dolarach i w złocie, kursy te bardzo szybko spadły, a gdy jeszcze zwiększyła się podaż wskutek napływu do Lublina dużych partii cudzoziemskich jeńców - kształtują się obecnie jak następuje: dolar papierowy 160 zł, 20 dolarów w złocie - 11500 zł.

\section{Ceny artykułów produkcji państwowej}

Na kształtowanie się poziomu cen na rynku wpływają również ceny artykułów produkcji państwowej, w szczególności - artykułów monopolowych i obłożonych akcyza, wypuszczanych na rynek po cenach niskich, 
przedwojennych czy okupacyjnych, [co] stało się przedmiotem spekulacji, władze pragnąc uniemożliwić "pasek” ustaliły cenę drożdży według ceny rynkowej w tym momencie (wrzesień 1944), a cena ta składała się z dwóch składników: ścisłej ceny w wysokości 10 zł za kg, dodając jednak akcyzę w wysokości $790 \mathrm{zł} \mathrm{od} \mathrm{kg.} \mathrm{W} \mathrm{rezultacie} \mathrm{tego} \mathrm{posunięcia} \mathrm{drożdże} \mathrm{po}$ 800 zł otrzymały tylko spółdzielnie, jednak do konsumenta drożdże te trafiały tylko z ulicznej sprzedaży i to po cenach niewspółmiernie wyższych. Ponieważ drożdże były surowcem dla producentów „bimbru” stały się przedmiotem prawdziwej giełdy drożdżowej i w Lublinie ceny dochodziły do 2200 zł za kg, załamując się z dnia na dzień np. do 1100 zł za $1 \mathrm{~kg}$. Na prowincji osiągano przejściowo ceny jeszcze wyższe np. przed wzięciem Warszawy w takim Otwocku płacono do 3200 zł za 1 kg drożdży. Dziś rozpiętość cen istnieje nadal (Lublin - do $1400 \mathrm{zl}$, Warszawa - $1700 \mathrm{zł}$ ) i drożdże są wciąż obiektem nieprowadzonej przez kupców spekulacji, której przydziały kartkowe po $5 \mathrm{dkg}$ nie mogą zwalczyć.

Co się tyczy artykułów przemysłowych produkcji państwowej - to niewątpliwie przyczyniły się one do spadku cen na rynku, np. za cement płacono na wolnym rynku w Lublinie przed otwarciem Zjednoczenia Cementu w Lublinie około 6000 zł za 1 t, obecnie zaś ze składów budowlanych można go nabywać po $2000-2300$ zł za 1 t. Ogromnie jednak mocno podkreślić należy konieczność starannej kalkulacji cen przed wypuszczeniem towaru, tak, żeby potem nie było potrzeba za często cen tych zmienić. Minister Minc w jednym ze swych przemówień podkreślił zaniedbywanie zasady rentowności przemysłu państwowego. Cała kalkulacja jest przejawem tego zaniedbania i wywołuje potem ten skutek, że np. odnośnie cementu w ciągu 6-ciu tygodni ceny „B" (dla odbiorców prywatnych) przechodzą następujące etapy: 1) 750 zł za 1 t loco stacja wysyłająca, 2) 1200 zł za 1 t jak wyżej plus 1200 zł od wagonu za konwój, i 3) 1200 zł za $1 \mathrm{t}$ jak wyżej plus 500 zł od t za konwój czyli 1700 zł za 1 t. Tego rodzaju fluktuacja cen pomijając ten wzgląd, że nie jest ona dobrym przykładem dla szerokich rzesz kupieckich powoduje chaos na rynku, dając albo podstawę do niezrozumiałej dla konsumenta rozpiętości cen - albo w razie zrównania cen na wolnym rynku - do nadmiernych zysków dla tych, którzy dawniej cement nabyli. Dodać do tego należy, że cena pierwotna 750 zł podana była przez Samopomoc Chłopską wsi, a gdy gminy, po zebraniu pieniędzy, przybywają po zakup, okazuje się, że cena wynosi już 1700 zł. Izba rozumie, że w momencie wielkiej płynności obecnych stosunków gospodarczych podobne sporadyczne wypadki są rzeczą nieunikniona, koniecznym natomiast jest, by tego rodzaju wypadki, z uwagi na ich refleksy na rynku, były nie regułą a rzadkim wyjątkiem. 
Wreszcie Izba pragnie poruszyć sprawę istnienia dwojakiego cennika: "A" dla władz, urzędów itp. i „B” dla prywatnego konsumenta czy kupca. Dwojakie cenniki mają zawsze to niebezpieczeństwo, że wobec wspomnianej płynności stosunków i czasem jeszcze niewłaściwej obsady stanowisk powodują pokusę dla nabywców, należących w rzeczywistości do grupy " $\mathrm{B}$ " - do usiłowania otrzymania towarów po cenie " $\mathrm{A}$ " celem dalszej odsprzedaży. Do wiadomości Izby dochodziły wieści o przedstawianiu punktom rozdzielczym pism, pochodzącym z urzędów, a proszących o wydanie odbiorcy prywatnemu pewnego towaru po cenie " $\mathrm{A}$, gdyż jest to rzekomo potrzebne do wykonania pewnych robót na obstalunek urzędu. Tylko solidarna postawa wszystkich zainteresowanych zwalczająca tego rodzaju obchodzenie przepisów w celach zysku i przestrzegania przepisanych formalności może zwalczać podobne usiłowania. W każdym razie Izba wypowiada przekonanie, że stosowanie podwójnych cenników, jak system kartkowy, czy udzielanie pracownikom wynagrodzeń w naturze bądź to za dużych deputatów towarowych rzucanych zaraz po spekulacyjnej cenie na rynek - winno być traktowane jako system przejściowy. W każdym razie system ten poddany być musi niezmiernie troskliwej i surowej kontroli, a o ile możność ograniczony do towarów kierowanych w starannie akumulowanych ilościach według norm osobistej konsumpcji - na przydziały, uzupełniające wynagrodzenie gotówkowe świata pracy.

\section{Komunikacja}

W uwagach wstępnych wspomniano o trudnościach komunikacyjnych, napotyka je w swojej pracy nie tylko Izba, lecz przede wszystkim przemysł i handel. Komunikacja kolejowa nie daje żadnych gwarancji określenia terminu nadejścia towaru. Wygórowane koszty komunikacji samochodowej uniemożliwiają wszelką logiczną kalkulację utrudniają ocenę marży zysku i powodują na rynku ogromne rozpiętości cen. Rozwiązanie tego problemu przy uwzględnieniu inicjatywy prywatnej jest rzeczą palącą. Poprawa wytworzonej w tej dziedzinie sytuacji możliwa byłaby przez utworzenie organizacji transporterów, umożliwienie im z materiałów demobilizacyjnych zaopatrzenia się w większą ilość samochodów ciężarowych i pod nadzorem np. samorządu gospodarczego objęcie pewnych odcinków komunikacyjnych na zasadach koncesji. System koncesjonowania linii dawał przed wojną dobre rezultaty, wpływając na obniżenie kosztów i poprawienie jakości transportów. 


\section{Zagadnienie środków pieniężnych}

Kapitalizacja - podstawowy element odbudowy gospodarki pieniężnej uległa poważnemu zahamowaniu i nie rokuje nadziei rozwojowych wobec dalszego drenowania rynku przez śrubę podatkową coraz mocniej i w różnych formach przykręcaną. Wszelkie wysiłki Państwa, by ruszyć z miejsca wypadkami wojennymi zahamowany przemysł, spotykają się zbyt często z brakiem potrzebnych na ten cel kapitałów w zbiornicach jakimi są banki. Dążąc do usystematyzowania gospodarki pieniężnej władze państwowe określiły sfery działania poszczególnych banków w rejonach przemysłowych, zalecając jednocześnie, by handel reaktywował działalność swą własnymi środkami, bez uciekania się do pomocy Państwa i banków. Być może byłoby to możliwe gdyby rozumiejąc swój interes, handel wolne swe chociażby chwilowo kapitały obrotowe lokować będzie w bankach, umożliwiając tym samym finansowanie bratnich swych jednostek potrzebujących pomocy. W finansowaniu przemysłu wykluczono materialną pomoc dla produkcji na skład. Tymczasem objawy deflacyjne, zniżka cen i zubożenie ludności - szczególnie głównego konsumenta, jakim jest rolnik - skróciła tak dalece popyt, że większość zakładów produkcyjnych dla wsi znalazło się w położeniu trudnym, nie może bowiem ani upłynnić remanentów wyrobów gotowych, ani uzyskać pomocy od państwa, czy banków, no i oczywiście nie posiada zniweczonych zabiegiem deflacyjnym rezerw kasowych. Dodać należy, że do pomocy $w$ tej dziedzinie potrzebne są kapitały tzw. średnioterminowe tj. pół i jednoroczne, którymi ani państwo, ani banki nie rozporządzają. Jeszcze trudniejsza sytuacja wytwarza się w koniecznym programie budownictwa. Palące te zagadnienie, pobudzając wydatnie w okresie rozwoju aktywność całego szeregu przemysłów, bezwarunkowo wymaga długoterminowych kapitałów, których nawet skonsolidowane organizmy państwowe szukały zawsze na zewnątrz. Dlatego też budownictwo nie oparte na jednorazowej dotacji państwa nie jest w stanie ruszyć z miejsca, a zdajemy sobie również dokładnie sprawę, iż nawet państwowe budownictwo, wobec ogromu zniszczeń w centrach takich jak Warszawa, Poznań czy Gdańsk, wysuszyłoby w krótkim czasie całą emisję banknotów, nie rozwiązując w żadnym stopniu zagadnienia odbudowy. Do wydatnego pobudzenia ruchy budowlanego należałoby zaprząc szeroką inicjatywę prywatna, stwarzając odpowiednią atmosferę dla jej powstania i rozwoju, a i tu łudzić się ani na chwilę nie powinniśmy, że nie da ona pożądanych rezultatów bez długoterminowego kredytu.

To zagadnienie atmosfery, przychylnej dla inicjatywy prywatnej, jest rzeczą pierwszorzędnego znaczenia. Panująca do dziś jeszcze w ośrod- 
kach prowincjonalnych niepewność co do losów średniego przemysłu i handlu, którą nie od razu rozproszą przemówienia Min. Przemysłu [Hilarego] Minca czy okólniki Min. Aprowizacji i Handlu [Jerzego] Sztachelskiego - (a to zwłaszcza wobec przemówienia p. Premiera na zjeździe Spółdzielczym) wywołała na tamtejszym terenie bankowym sytuację specyficzną. Przemysł i handel powstrzymuje się od obrotów i tym samym powstrzymuje się od zaciagania kredytu. W tej chwili banki lubelskie nie tylko, że nie oprocentowują wkładów, lecz przeciwnie - pobierają opłatę za przechowanie pieniędzy. Należy spodziewać się, że ta paradoksalna sytuacja w związku z pobudzeniem aktywności całego życia gospodarczego, które choć słabo zaczyna się jednak zarysowywać, ulegnie zmianie.

\section{SYTUACJA PRZEMYSŁU OKRĘGU IZBY}

Gdy w lipcu 1944 roku cofające się wojska niemieckie osiągnęły linie Bugu, władze okupacyjne zaczęły czynić gorączkowe przygotowania do wywiezienia maszyn i urządzeń przemysłowych z Lubelszczyzny w głąb Niemiec, względnie do usunięcia najbardziej cennych części tych maszyn i urządzeń, aby w ten sposób uniemożliwić uruchomienie fabryk. Udało się to im jednak w znikomej części, gdyż odwrót niemców z woj. lubelskiego odbył się $w$ tak niespodziewanie szybkim tempie i tak chaotycznie, że właściwie żaden z zakładów porządnie nie ucierpiał. Chociaż w każdej fabryce były przez nalepienie specjalnych kartek dokładnie oznaczone te części maszyn i urządzeń, które na dany rozkaz miały być zniszczone lub też załadowane na samochody i wysłane na zachód, to jednak do tego prawie nigdzie nie doszło. Jest to $\mathrm{w}$ wielkiej mierze zasługa polskiego personelu fabryk, który nieraz z narażeniem życia sabotował zarządzenia niemców, wprowadzał ich w błąd albo też tak długo odwlekał wykonanie zarządzeń ewakuacyjnych, aż póki sami niemcy nie musieli myśleć już tylko o sobie i ratować się ucieczką. Praktycznie więc biorąc przemysł lubelski przetrwał powrotną falę okupantów niemieckich dość pomyślnie, nie doznając specjalnie przykrych spustoszeń w maszynach i urządzeniach, a nawet zachowując pewne ilości surowców i półfabrykatów.

Niestety przez pierwszych kilka tygodni po odejściu niemców nowe władze nie były w stanie zapewnić zakładom przemysłowym dostatecznej opieki, z czego skorzystały niemoralne elementy ludności miejscowej, wykradając z fabryk mniejsze silniki elektryczne, narzędzia, żarówki itp. Tym i innym okolicznościom o charakterze administracyjno prawnym (np. tytuł własności, prawa dyspozycji itp.) przypisać należy, że całe mnóstwo zakładów uruchomiono dopiero na jesieni. 
Okoliczności w jakich przemysł podejmował pracę nie były jednak zachęcające. Surowców na rynku albo było brak, albo też żądano za nie wysoko wyśrubowane ceny; robotnicy zażądali podniesienia zarobków do takiej wysokości, która umożliwiłaby im pokrycie kosztów utrzymania przy zakupie artykułów spożywczych na wolnym rynku; środków komunikacyjnych nie było, a rynek zbytu gotowych fabrykatów ograniczał się do najbliższego otoczenia. Obliczenie kosztów własnych w takich warunkach - a co za tym idzie - ustalenie ceny sprzedażnej było wręcz niemożliwe, transakcje kupna i sprzedaży zawierane więc były od wypadku do wypadku. Głównym odbiorcą była ludność wiejska, która przy zakupie towaru część należności pokrywała gotówka, część uiszczała w postaci artykułów żywnościowych, które były rozdzielone pomiędzy załogę fabryki. Obecnie sytuacja nieco się polepszyła, jednakże tego rodzaju „handel zamienny" jeszcze jest w dalszym ciagu stosowany.

Przechodząc z kolei do opisu poszczególnych gałęzi przemysłu w województwie lubelskim, zaznaczyć należy raz jeszcze, że w przytoczonych dalej zestawieniach cyfrowych tylko dane $z$ samego miasta Lublina sa kompletne, natomiast dane $\mathrm{z}$ powiatów województwa kompletne nie sa, albowiem wobec trudności komunikacyjnych z całym szeregiem gmin nie udało się dotychczas nawiązać kontaktu. Na pisma skierowane przez Izbę Przemysłowo-Handlową do gmin i zarządów miejskich od co najmniej połowy gmin odpowiedzi dotychczas nie otrzymano.

Jeżeli porównać dane liczbowe, zawarte w poniższych danych o poszczególnych przemysłach - względnie wykazie załączonym jako „załącznik nr $1^{\prime \prime} 5$ - z liczbami przedwojennymi umieszczonymi w ostatnim sprawozdaniu Izby Przemysłowo-Handlowej w Lublinie za rok 1937 to rzuca się w oczy ogromna różnica podanej w obydwu wykazach ogólnej liczby wykazów [zakładów?] przemysłowych. Podczas gdy w załączonym wykazie ogólna liczba czynnych zakładów przemysłowych wynosi 510, to w 1937 roku liczba ta stanowiła 5714. Różnica ta uzasadniona jest następującymi okolicznościami:

1. Sprawozdanie za rok 1937 oparte jest na podziale przedsiębiorstw według kategorii świadectw przemysłowych od I do VIII, przy czym do ostatnich dwóch kategorii (VII i VIII) zaliczone zostały przedsiębiorstwa o charakterze rzemieślniczym, natomiast wykaz obecny obejmuje tylko te przedsiębiorstwa, które prowadzone są sposobem fabrycznym.

2. Cały szereg drobnych zakładów przemysłowych został zlikwidowany przez okupantów a mianowicie: małe młyny wodne, olejarnie, cegielnie polowe i wapniarki, przedsiębiorstwa eksploatacji lasów, drobne tartaki oraz cały przemysł szczeciniarski.

\footnotetext{
${ }^{5}$ Załącznika nie udało się odnaleźć.
} 
3. W rezultacie reformy rolnej szereg przedsiębiorstw, jak tartaki, młyny, cegielnie itd. ma przejść bądź to w ręce Państwa, bądź spółdzielni, bądź prywatnych nabywców. W bardzo wielu wypadkach sprawa przewłaszczenia nie jest jeszcze dokonana i przedsiębiorstwa są nieczynne i kart rejestracyjnych nie wykupiły.

4. Około 50\% zarządów gminnych na prowincji nie nadesłało odpisów deklaracji na wykupienie karty przemysłowo-podatkowej. Wystosowane przez Izbę monity nie odniosły dotychczas skutku.

5. Cały szereg zakładów przemysłowych średnich i drobnych bądź to wstrzymuje się z zakupieniem karty przemysłowo-podatkowej nie mogąc chwilowo pokonać piętrzących się trudności, bądź też szczególnie przy drobnych zakładach uchyla się od rejestracji tworząc tzw. dziki przemysł. Należy przypuszczać, że jednak odnośne władze przez wydanie rygorystycznych zarządzeń i przeprowadzenie kontroli stan ten niedługo ukrócą.

\section{Przemysł Spożywczy}

$\mathrm{Na}$ terenie województwa lubelskiego zostały w pierwszej połowie 1945 r. wykupione następujące karty przemysłowo-podatkowe:

52 szt. kart przemysłowo-podatkowych kategorii IIa

112 , IIb

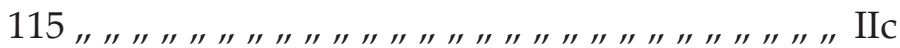

razem 279 sztuk

W ilości tej nie uwzględniono wiatraków, młynów o mocy poniżej $25 \mathrm{KM}$, ponieważ zakłady te przez okupanta zaliczone zostały do rzemiosła, a Izba Rzemieślnicza nadal utrzymuje je w swojej ewidencji. Sprawa ta jest przedmiotem ankiety Ministerstwa Przemysłu odnośnie zmiany listy rzemiosł. W 1937 r. w tym dziale wykupiło świadectwa przemysłowe 3465 przedsiębiorstw, między innymi 8 cukrowni i rafinerii, 895 młynów motorowych, parowych i wodnych, 701 wiatraków /patrz 2-ga uwaga wstępna/, 355 olejarni, 365 kaszarni - dziś w trakcie przejmowania przez spółdzielnie - i 177 fabryk wód gazowanych, które również podleg[a]ły likwidacji, przez niemców; dziś jest ich 38.

Ilość osób zatrudnionych w przemyśle spożywczym wynosi 2893 a moc maszyn zainstalowanych w zakładach przemysłowych 17042 KM. Obrót osiągnięty przez te zakłady w ubiegłym roku wyraża się cyfrą 85778665 zł, jednakże odzwierciedla ona rzeczywisty stan rzeczy tylko $\mathrm{w}$ małym przybliżeniu, ponieważ $\mathrm{w}$ większych zakładach księgi buchalteryjne zostały przez niemców zniszczone i podane przez firmy obroty obejmują tylko okres od sierpnia ubiegłego roku począwszy. 
Do kampanii zimowej ubiegłego roku przystąpiło tylko 5 cukrowni, pozostałe 4 cukrownie nie mogły być uruchomione, ponieważ niemcy wywieźli z nich niektóre części maszyn i urządzeń. Jednakże kierownictwo tych cukrowni dokłada wszelkich starań, aby zakłady ponownie uruchomić i należy przypuszczać, że w następnej kampanii wezmą udział już wszystkie cukrownie okręgu lubelskiego. Cukrownie, które były czynne, osiągnęły najwyżej 50\% swej normalnej wydajności, głównie z powodu braku węgla i kamienia wapiennego, sprowadzanego z okręgu kieleckiego, oraz trudności transportowych ze zwózką buraków.

Gorzelnie i rektyfikacje spirytusu również w niewielkiej tylko części osiągnęły swoją normalną wydajność.

To samo można powiedzieć i o wszystkich innych zakładach przemysłu spożywczego jak browary, octowniach i olejarniach itp., ponieważ wszystkie one wskutek niedomagań transportu kolejowego odczuwają brak surowców do produkcji oraz najgłówniejszego materiału napędowego jakim jest węgiel. Z chwilą usprawnienia ruchu kolejowego sytuacja przemysłu spożywczego ulegnie poprawie.

\section{Przemysł Metalowy \\ W przemyśle metalowym zarejestrowano: \\ 13 zakładów wg. kategorii przemysłowej IIa \\ 2 , ", IIb

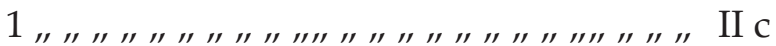

W $1937 \mathrm{r}$. było zarejestrowanych 74 przedsiębiorstwa.

Liczba osób zatrudnionych wynosi 815 , a obrót ogólny wyraża się cyfrą 17418602 zł. Wydajność zakładów nie przekracza 50\% stanu normalnego, główną bolączką jest brak surowców, brak narzędzi i brak wykwalifikowanych robotników. Zakłady tej gałęzi przemysłu są w przeważnej części nastawione tylko na wyrób maszyn i urządzeń rolniczych, a w chwili obecnej właściwie raczej na remont maszyn rolniczych, ponieważ ze strony ruchu budowlanego żadnego zapotrzebowania na okucia itp. nie ma. Czynna jest poza tym jedna fabryka silników i jedna fabryka narzędzi precyzyjnych oraz trzy fabryki wag.

\section{Przemysł Garbarski i Skórzany}

Przed wojną w dziale tym wykupiły karty przemysłowe 33 przedsiębiorstwa: 5 garbarni, 6 solarni, i 22 wytwórnie galanterii (rzemiosło). Obecnie przemysł garbarski skoncentrowany jest w Lublinie, gdzie znajduje się obecnie 5 garbarni i jedna fabryka pasów transmisyjnych i uprzęży. Zakłady te wykupiły na rok 1945 karty przemysłowe kategorii IIa, zatrudniają 238 osób i osiągnęły w ubiegłym roku obrót w wysokości 3388428 zł. 
Garbarnie produkują skóry podeszwowe, bukaty i juchty. Wszystkie zakłady są czynne i pracują normalnie, a jak widać z porównania z okresem przedwojennym przemysł ten nie ucierpiał ilościowo.

\section{Przemysł Chemiczny}

Do przemysłu chemicznego należą fabryki mydła, lakierów, farb, pokostu i świec oraz wytwórnie perfumeryjno kosmetyczne i jedna wytwórnia kwasu węglowego. Z ogólnej liczby 17 zakładów:

5 zakładów wykupiło kartę przemysłową kategorii IIa

7 , " IIb

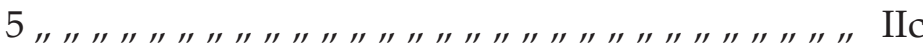

Zatrudniają one 128 pracowników, moc maszyn zainstalowanych wynosi 75 KM, obrót wyraża się kwotą 3606221 zł. Są to na ogół przedsiębiorstwa niewielkie i osiągają one około 50\% swej normalnej wydajności. I tu również odczuwa się brak surowców i opakowań (butelek, słoików, kartonów itp.). Przed wojną w dziale tym pracowało 108 przedsiębiorstw, w tym 34 fabryki a raczej fabryczki mydła, 19 smolarni, 8 terpentyniarni, 8 wytwórni lepów itp.

\section{Przemysł Konfekcyjny}

Przemysł konfekcyjny reprezentowany jest przez jedną fabrykę obuwia, jeden zakład wyrobów trykotarskich i dwie pralnie i farbiarnie chemiczne, ponieważ pozostałe 52 firmy są to pralnie ręczne i magle, które właściwie należeć powinny do rzemiosła.

Wspomniane 4 większe zakłady zatrudniają 420 robotników, posiadają maszyny i silniki o łącznej mocy 104 KM i osiągnęły ogółem obrotu zł 4245 619. Stan zatrudnienia w tych zakładach jest normalny, trudności pochodzą z braku węgla i barwników. Przed wojną z tego działu przemysłu wykupiło świadectwa przemysłowe 112 przedsiębiorstw, 3 fabryki obuwia, 44 wytwórnie trykotarzy, 17 wytwórni kołder i 48 pralni.

VI. Przemysł Wydawniczy i Poligraficzny

Ogólna liczba czynnych zakładów wynosiła 19, przy czym:

5 zakładów wykupiło świadectwa przemysłowe kategorii IIa

4 IIb

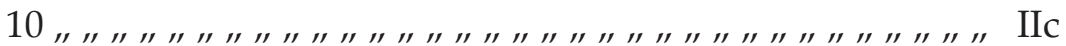

W zakładach tych pracuje 212 osób, moc maszyn zainstalowanych wyraża się cyfrą $70 \mathrm{KM}$, a obrót osiagnnięty w roku ubiegłym kwotą 5483224 zł. Wszystkie zakłady pracują normalnie, a nawet $\mathrm{z}$ nadmiarem zamówień, trudności polegają głównie na braku normalnych dostaw 
papieru. Przed wojną pracowało 78 zakładów, w tym 76 drukarni (które w czasie okupacji podległy w znacznej części likwidacji przymusowej) i 2 litografie.

VII. Przemysł Przedsiębiorstw Robót Budowlanych

Ta gałąź przemysłu, jak wspomniano już wyżej, jest właściwie zupełnie unieruchomiona, ponieważ $\mathrm{w}$ chwili obecnej wszelki ruch budowlany ustał.

Zarejestrowało się w roku 1945 ogółem 10 przedsiębiorstw (w 1937 35), z tej liczby 8 firm w samym Lublinie.

Firmy te wykupiły karty przemysłowo-podatkowe kategorii IIa, zatrudniają 196 osób i podały jako osiągnięty w ub. roku obrót kwotę 2386522 zł. Przedsiębiorstwa budowlane, które patentów w ogóle nie wykupiły, istnieją w dalszym ciągu i oczekują na polepszenie się koniunktury, gdyż odbudowa kraju musi przecież ruszyć z miejsca.

\section{Przemysł Papierniczy}

Przemysł papierniczy reprezentuje tylko jedna fabryka torebek i innych opakowań z papieru i kartonów. Firma ta wykupiła kartę przemysłowo-podatkową wg kategorii IIc, zatrudnia 12 ludzi i osiągnęła w ub. roku obrót w sumie 90000 zł. W 1937 r. fabryk torebek było 13, poza tym 5 wytwórni gilz, 15 wytwórni kajetów, 3 wytwórnie papy.

\section{Przemysł drzewny}

Przemysł ten obejmuje tartaki, fabryki mebli giętych, fabrykę kopyt i szpilek szewskich oraz fabrykę beczek. Podział firm według wykupionych kart przemysłowo-podatkowych przedstawia się następująco:

5 firm wykupiło kartę kategorii IIa

7 , IIb

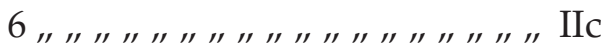

Liczba zatrudnionych wynosi 457, moc maszyn zainstalowanych 833 KM, a obrót w ubiegłym roku 6529965 zł. Ponieważ zakłady te znajdują się $\mathrm{w}$ większości na prowincji i osobistego kontaktu z nimi nie ma, trudno jest powiedzieć coś pewnego o ich położeniu gospodarczym, przypuszczać jednak należy, że i one również nie mogą stanąć na normalnym poziomie tak długo, aż póki nie będzie należycie usprawniony ruch kolejowy.

Fabryki mebli giętych musiały się przestawić podczas okupacji na wyrób mebli zwyczajnych i sprzętu dla szpitali i wojska i prawdopodobnie swej normalnej produkcji jeszcze nie podjęły. Przed wojną w dziale tym zarejestrowane było 794 przedsiębiorstwa np. 248 tartaków (patrz uwagi 
na wstępie tego działu), 363 przedsiębiorstwa eksploatacji lasów - dziś lasy państwowe - i szereg przedsiębiorstw raczej rzemieślniczych, wyrabiających klepki czy podkłady, poza tym jedna beczkarnia, 8 fabryk mebli giętych, 2 fabryki kopyt i szpilek i 2 fabryki posadzek.

\section{Przemysł Mineralny}

Do tej gałęzi przemysłu należą kamieniołomy i wapienniki, cegielnie i kaflarnie, huty szkła oraz fabryki cementu. Ogólna liczba zarejestrowanych zakładów wynosi 18 (przed wojną 382 w tym 239 cegielni, 77 betoniarni i 7 hut szklanych), ilość zatrudnionych osób 59, moc maszyn zainstalowanych 10 KM i obrót w ubiegłym roku zł 632000.

Zaznaczyć należy jednak, że tylko 9 zakładów wykupiło karty przemysłowo-podatkowe a mianowicie:

2 zakłady wykupiły kartę kategorii IIa

2 IIb

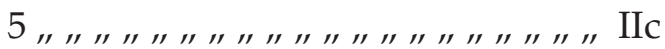

Nie uwzględniona jest jeszcze fabryka Portland-Cementu w Rejowcu powiat chełmski, o której nie posiadamy bliższych danych co do obecnego jej stanu zatrudnienia. W każdym razie jest ona czynna. Cegielnie są prawie wszystkie nieczynne, ponieważ nie ma wcale zapotrzebowania na cegłę wobec stagnacji w przemyśle budowlanym. Brak również danych co do kopalni fosforytu w Annopolu powiat Janów oraz co do klinkierni w Zamojszczyźnie.

\section{Przemysł Włókienniczy}

W tym dziale reprezentowane są tylko tzw. gręplarnie waty w liczbie 9 (w 1937 r. - 15), które wszystkie wykupiły karty przemysłowo-podatkowe kategorii IIc, zatrudniają 14 osób, posiadają silniki o mocy $11 \mathrm{KM}$ i osiągnęły łączny obrót w sumie 110000 zł w ubiegłym roku.

Są to wszystko przedsiębiorstwa drobne, używające szmaty jako produktu wyjściowego.

\section{Przemysł Energetyczny}

Tu mamy do czynienia jedynie z trzema prywatnymi zakładami elektrowniami (przed wojna było 35 elektrowni prywatnych i komunalnych), mającymi na celu okolicznościowy zbyt energii elektrycznej w najbliższym otoczeniu. Zakłady te uprawiają poza tym jeszcze inny przemysł, gdyż prowadzą jednocześnie młyn zbożowy albo tartak. Wszystkie one wykupiły karty przemysłowo-podatkowe kategorii IIc, zatrudniają 24 pracowników i mają maszyny o mocy $285 \mathrm{KM}$. Obrót ich w roku ubiegłym wynosił 308723 zł. 
Nie uwzględnione są tutaj elektrownie w Lublinie i Zamościu, które stanowią własność komunalną, a także i tzw. „Lubzel” - Lubelski Międzykomunalny Związek Elektryfikacyjny, który siecią swą obejmuje prawie całe województwo lubelskie, a energię czerpie z zakładów elektrycznych w Lublinie, Zamościu i Nisku (Stalowa Wola).

Działalność „Lubzelu” jest w skutkach swoich bardzo dodatnia, ponieważ umożliwia uprzemysłowienie wsi i daje jej tanią i zdrową energię świetlna, zamiast kopcących niezdrowych i pod względem pożarowym niepewnych lamp naftowych i karbidowych,

Związek ten był przez cały czas okupacji czynny i przetrwał zawieruchę wojenną bez specjalnych wstrząsów.

\section{Przemysły różne}

Tu zaszeregowane są drobne przedsiębiorstwa przemysłu usługowego (gabinety kosmetyczne, wagi osobowe itp.); jest razem 6 zakładów w których pracuje 10 osób. Wszystkie one wykupiły karty kategorii IIc i podały jako obrót ub. roku sumę $247000 \mathrm{zł}$.

Tak reprezentuje się $\mathrm{w}$ ogólnych zarysach stan przemysłu w Województwie Lubelskim, odtworzony na podstawie danych, zawartych w składanych przez poszczególne zakłady przemysłowe deklaracjach przy nabyciu kart przemysłowo-podatkowych. Ogólne zestawienie wyników podane jest na załączonym wykazie statystycznym czynnych obecnie na terenie województwa lubelskiego zakładów przemysłowych (wg stanu z czerwca 1945 r.) z podziałem na poszczególne gałęzie przemysłu i na powiaty. (Załącznik nr 1).

\section{SYTUACJA HANDLU W OKRĘGU IZBY}

Struktura handlowa okręgu Izby uległa na przestrzeni lat 1939-1945 zasadniczym zmianom. W okresie przedwojennym okręg Izby zajmował jedno z poważniejszych stanowisk $w$ polskim eksporcie - tym samym posiadał $\mathrm{w}$ dziedzinie pewnych gałęzi handlu dobrze rozwinięty i oparty o wystarczające podstawy kapitałowe - hurt.

Eksport z terenu Izby z uwagi na wybitnie rolniczy charakter Lubelszczyzny dotyczył przede wszystkim ziemiopłodów (zbóż, chmielu), drzewa, skór, szczeciny, jaj i mięsa. W epoce kontyngentów i potrzeb wojska polskiego i rosyjskiego, a w ogóle sytuacji powojennej, nie tylko o eksporcie, ale o handlu hurtowym zbożem czy drzewem na właściwą skalę nie ma mowy. Nie przeszkadza to faktowi, że Lubelszczyzna stale jest spichrzem dla reszty kraju i że aparat spółdzielczy przekazywał na apro- 
wizację wojska i miast poza okręgiem Izby znaczne ilości zbóż. Żadnych cyfr konkretnych na razie jeszcze Izba w tej dziedzinie nie uzyskała.

Co się tyczy chmielu, to wobec całkowitego zniszczenia chmielników i nieuregulowania dotąd tytułu własności odnośnych obiektów na racjonalną produkcję, a cóż dopiero na możliwości eksportowe, nie należy zapatrywać się zbyt optymistycznie. Natomiast na tym miejscu należy wspomnieć o jednorazowym wywozie sadzonek chmielarskich, których $1 / 2$ miliona wysłano do ZSRR.

Parę słów poświęcić należy wybitnemu artykułowi, jakim była szczecina, której z okręgu Izby wywieziono w r. 1936 - 311692 kg. Ośrodek produkcji, znajdujący się w Międzyrzecu, uległ całkowitemu zniszczeniu, gdyż zarówno robotnicy jak i skupujący szczecinę rekrutowali się wyłącznie z pośród Żydów. Tereny dostawy surowca, tj. szczeciny, świń hodowlanych sposobem tzw. „dzikim”, znajdują się za Bugiem. Ostatnio jeden z wybitnych fachowców szczeciniarskich udał się do Miedzyrzeca dla przestudiowania zagadnienia, specjalnie jednak korzystne jego rozwiązanie nie wydaje się rzeczą mającą szanse powodzenia.

W zakresie wywozu w ramach przyszłych rozrachunków z ZSRR dokonano ostatnio kilku transakcji, a mianowicie wywożono cukier z Cukrowni Lublin i z innych, a także cement z fabryki „Firlej” w Rejowcu. Szczegółów tych transakcji, jak również danych o pozostałym wywozie $\mathrm{w}$ tym zakresie, na razie brak. $W$ każdym razie transakcje te nie moga być również uważane - ani za działalność eksportową $\mathrm{w}$ całym tego słowa znaczeniu - ani za przejaw działalności kupieckiego hurtu. Hurt, $\mathrm{w}$ niewystarczającym zresztą zakresie, reprezentuje niemal wyłącznie „Społem”, które jednak zupełnie nie zaopatruje kupiectwa prywatnego.

Ilość świadectw przemysłowych, wykupionych na prowadzenie handlu na terenie województwa lubelskiego (razem z m. Lublinem) wyniosła w roku 1937 - 33151, przy czym dzieliły się one wg kategorii w sposób następujący:

$$
\begin{aligned}
& \text { I - } 14 \\
& \text { II - } 762 \\
& \text { III - } 5898 \\
& \text { IV - } 26390 \\
& \text { V - 87 }
\end{aligned}
$$

Zaznaczyć należy, że przed wojną obserwowano znaczny przyrost przedsiębiorstw handlowych wszystkich, a nie tylko najniższej IV, kategorii, a więc i również I i II, co dowodziło koncentracji hurtu, a także przestawienia się handlu na sprzedaż produkcji wytworniejszej; pozosta- 
wało to w związku z wyższą stopą życiową ludności i wzrostem jej wymagań.

Okres okupacji zaznaczył się ogromnym zmniejszeniem ilości przedsiębiorstw handlowych, co przede wszystkim przypisać należy akcji skierowanej przeciwko Żydom, których przedsiębiorstwa, według dokonanego szacunku, wynosiły przed wojną $52-54 \%$ ogółu przedsiębiorstw. Wobec braku przedwojennych kartotek Izba za pośrednictwem gminy żydowskiej prowadzi obecnie badania, mając na celu ustalenie w ramach możliwości ilości przedsiębiorstw handlowych żydowskich i ich strat. Prace te, prowadzone na życzenie Min. dr. [Emila] Sommernsteina, który opracowuje zagadnienie odszkodowań wojennych, nie są jeszcze ukończone i wobec bardzo krótkiego, a i tak z konieczności przekroczonego terminu złożenia niniejszego sprawozdania Ministerstwu, już w nim nie będą mogły być uwzględnione, i zostaną omówione dopiero w sprawozdaniu za rok 1945. Wszystkie firmy żydowskie istniejące przed wojną zostały przejęte przez niemców, na miejsce zaś innych z czasem, zwłaszcza po wsiach, powstały firmy polskie.

Dalsza likwidacja firm nastąpiła na skutek zarządzeń okupacyjnych „czyszczących” pewne branże, bądź w drodze zamykania, bądź w drodze łączenia dwóch czy kilku przedsiębiorstw w jedno. Akcja ta dotknęła najmocniej przedsiębiorstwa tekstylne, papiernicze, branży żelaznej i art. gospodarstwa domowego. Jednocześnie $\mathrm{w}$ stale tak tytułowanym przez niemców „prastarym mieście niemieckim” Lublinie powstało sporo firm niemieckich $\mathrm{w}$ lokalach wysiedlonych na peryferia miasta firm polskich.

Po wypędzeniu niemieckiego okupanta na rynku handlowym zapanował chaos, wywołany stratami w budynkach i towarze, a z drugiej strony dążeniem do odzyskania dawnych lub uzyskania nowych lokali. Miasto Lublin, które stało się siedzibą władz centralnych i miejscem ucieczki tysięcy uchodźców, przechodziło i przechodzi do dziś poważny kryzys mieszkaniowy. Nieudolność Urzędu Mieszkaniowego w połączeniu z samodzielnymi decyzjami władz i wojska stworzyły atmosferę zadrażnień, zwłaszcza wskutek masowych wysiedleń z mieszkań i domów, dokonywanych $z$ natychmiastowym rygorem. Szeregiem pięknych poniemieckich sklepów zawładnęła Lubelska Spółdzielnia Spożywców i sklepy te do dawnych przedwojennych właścicieli nie powróciły. W mieście zaś powstało wiele przedsiębiorstw koniunkturalnych jak np. sklepy komisowe i inne przedsiębiorstwa handlowe, które zakładali uchodźcy z Warszawy i innych terenów, którzy wrócili do siebie.

Według danych kartoteki Izby, danych niekompletnych o ile chodzi o poszczególne powiaty, bo szereg gmin jeszcze nie nadesłało sprawoz- 
dań ze sprzedaży kart przemysłowo-podatkowych, w chwili obecnej na terenie Izby znajduje się 5807 przedsiębiorstw handlowych (patrz załącznik nr 2) ${ }^{6}$. Przedsiębiorstwa te według kategorii świadectw, które wykupywane są na zupełnie innych zasadach niż przed wojną grupują się jak następuje:

$$
\begin{gathered}
\text { Kat[egoria] Ia }-532 \\
\mathrm{Ib}-4.835 \\
\text { IV }-53 \\
\text { V }-156 \\
\text { VIII }-4 \\
\text { IX }-227
\end{gathered}
$$

W samym mieście Lublinie znajduje się 1659 firm. Uzyskano dane o przeszło 1000 spośród nich pozwoliło Izbie obliczyć zeznane przez te firmy obroty za rok 1944, co dało cyfrę złotych 1372606960. Niekompletne dane opracowane dla całego terenu Izby ustaliły obroty w wysokości 1808477329 zł; wobec braku danych z szeregu firm a m.in. znacznych, a w obliczeniu nie uwzględnionych obrotów sklepów „Osobtorgu” obroty w 1944 można szacować dla całego okręgu na co najmniej trzy i pół miliarda złotych.

Charakter ogółu przedsiębiorstw handlowych okręgu Izby jasno wynika z poniższego uszeregowania poszczególnych branż kupieckich:

sklepów: spożywczych i art.. kolonialnych 1.746

galanteryjnych 573

owocarni 566

herbaciarni 220

restauracji 161

piwiarni 154

przedsiębiorstw dorożkarskich 152

wędliniarskich i mięsnych 122

naczyń kuchennych i gosp. domowego 121

owoców i jarzyn 113

mieszanych towarów 88

jadłodajni 79

piśmiennych materiałów 77

cukierni i kawiarni 71

aptek 65

szewskich wyrobów 63

pieczywa i wyrobów cukierniczych 50

\footnotetext{
${ }^{6}$ Załącznika nie udało się odnaleźć.
} 
Pozostałe sklepy różnych branż przedstawiają nieznaczne ilości patrz szczegóły na załączniku nr 2.

Jak z powyższego wynika, zasadniczym typem sklepów zarówno w mieście jak i na wsi jest sklep spożywczy, w praktyce właściwie będący sklepem towarów mieszanych.

W każdym niemal zarówno prywatnym jak i spółdzielczym tzw. sklepie spożywczym, których, o ile chodzi o Lublin, mieści się po kilka w jednym domu, znajdują się nie tylko najróżniejsze towary spożywcze od bułek przez ciasta, wędliny, mięso, słodycze, drożdże i jarzyny - aż do wódki i esencji octowej - lecz i szereg innych artykułów gospodarstwa domowego, jak proszki do czyszczenia, farby, mydło, ,kogutki”, pasta do butów i podłóg, szczotki, nici, kremy kosmetyczne itp. Konsument cierpi na tym podwójnie, bo w sklepach ze względów lokalowych ma mały wybór artykułów, a ponieważ kupcy kupują je zwykle od domokrążnych agentów i pośredników, płaci ceny wyższe, niż gdyby udał się do sklepu o rzeczywiście sprecyzowanej branży. Kupiec traci, gdyż wobec nadmiaru gatunków towarów ma nadmiar klientów zapełniających sklep, z których wielu nie znajduje właściwego towaru i zabierając dużo czasu, nic nie kupuje. W tych warunkach kupiec nie może rentownie planować swojego zakupu, co mu zmniejsza obroty. Na drugim z kolei miejscu stojące pod względem ilości sklepy galanteryjne - są to sklepy również o charakterze mieszanym, dotyczy to nieraz i sklepów materiałów piśmiennych. Widok wystaw sklepów komisowych, na których umieszczono bez wyboru wszelkie towary, zachęcił i inne sklepy bądź do uprawiania nielegalnego komisu, bądź do przerzucania się na towary innych branż. Sklepy branżowe w ścisłym tego słowa znaczeniu są obecnie stosunkowo bardzo nieliczne.

Powyższe zjawisko jest dość typowym powojennym objawem, charakteryzującym momenty kryzysów i przesileń gospodarczych. Zwalczanie tego zjawiska w obecnej chwili w sposób zbyt kategoryczny czy przymusowy jeszcze nie jest może właściwe ze względów socjalnych, gdyż każdy sklep niemal wyżywia dużą rodzinę albo kilka rodzin. Nie trzeba chyba jednak uzasadniać, że zarówno prawdziwy interes kupca jak i względy logiczne, higieniczne, estetyczne czy podatkowe czynią $\mathrm{z}$ tego zagadnienia sprawę, która po pewnym powrocie do normalniejszych warunków życia musi tam, gdzie w zetknięciu z życiem sama nie zginie, w drodze interwencji samorządu gospodarczego i organizacji kupieckich znaleźć właściwe rozwiązanie. Nawiasem zaznaczyć należy, że uwaga ta dotyczy również bardzo rozwiniętego i stwarzającego ogromną konkurencję osiadłemu kupiectwu handlu ulicznego nie opłacającego przeważnie żadnych opłat, z wyjątkiem placu koło hal targowych, na 
którym codziennie przesuwają się tysiące sprzedających i kupujących. I tu względy socjalne powodują tolerowanie przerostu tego rodzaju handlu.

Jedna z przyczyn stwarzających dla sklepów warunki sprzyjające zatraceniu charakteru branżowego jest brak na miejscu hurtu, wskutek czego kupiec zaopatruje się $\mathrm{w}$ towary przeważnie od przygodnych sprzedawców, którzy mają zazwyczaj do dyspozycji towar różnorodny, ale w stosunkowo małych ilościach. Do omówienia więc pozostaje kwestia, dlaczego kupiec nabywa nieraz byle jaki towar, przyniesiony mu do sklepu, a nie zmobilizuje sam lub do spółki pewnej ilości gotówki dla sprowadzenia sobie od wytwórcy lub $\mathrm{z}$ hurtowni w innym centrum gospodarczym danego artykułu. Otóż ospałość i zła komunikacja nie są tu motywami decydującymi, chodzi raczej o specyficzny charakter ryzyka, jakie taka transakcja by za sobą pociągała. Ryzyko kupieckie w handlu, możliwość strat i manca, są to stałe składniki przezornej kalkulacji. W danym jednak wypadku decydującą o tej pełnej rezerwy postawie całego kupiectwa rolę odegrało inne ryzyko, że się tak wyrazimy koniunkturalne. Kupiectwo nie było pewne swojego jutra. Mocne i aprobowane w oświadczeniach osób urzędowych wypowiedzi ze strony spółdzielczości, wskazujące na jej dążenia do przejęcia całego handlu, co np. w Lublinie poparte było zajęciem przez nią szeregu najpiękniejszych sklepów w śródmieściu, dalej ostre ataki prasowe na kupiectwo, utożsamiane ze spekulantami - to wszystko $\mathrm{w}$ połączeniu $\mathrm{z}$ posiadanymi informacjami jak zreorganizowano handel w ZSRR - wywołało i dla kupiectwa i wśród kupiectwa nieprzychylną dla szerszych transakcji i przejawów inicjatywy atmosferę. W rezultacie kupiectwo lubelskie z nielicznymi wyjątkami przybrało postawę wegetatywna, wyprzedając dawny towar i uzupełniając zapasy w sposób bardzo ostrożny. Nastrój ten odbił się także i na cenach, gdyż dopóki kupiec nie wie, czy dana transakcja nie jest ostatnia w jego samodzielnej karierze dotąd nie spieszy się ze zniżką cen według racjonalnej kalkulacji, zwłaszcza, że szansa prawa odkupu nie była wyjaśniona. Oświadczenia czołowych przedstawicieli naszego rządu, w szczególności Min. Minca i Min. Sztachelskiego, ogromnie uspokoiły panikarskie nastroje, choć podkreślić należy, że już z chwila przesunięcia frontu i oswobodzenia od niemców reszty Polski wiele aktywniejszych jednostek zaczęło okazywać kupiecką inicjatywę. W chwili obecnej kupiectwo studiując uważnie przekształcony wskutek zmiany siły nabywczej poszczególnych klas rynek, rusza się już i poważnie myśli o przygotowaniach do jesiennego sezonu, zwłaszcza że podaż poszukiwanych towarów nie jest na miejscu wystarczająca, w związku z czym są czynione usiłowania mające na celu przywrócenie handlu hurtowego. Również i zewnętrzny wygląd sklepów uległ popra- 
wie, w szczególności okna wystawowe, zasłonięte do niedawna cały dzień deskami rzekomo w obawie nalotów, a w rzeczywistości by nie przyciągały klientów, zdobywają się już nawet na pewien wysiłek estetyczny.

\section{ZAKOŃCZENIE}

Kończąc swe pierwsze powojenne sprawozdanie, Izba pragnie podkreślić, że starając się poruszyć możliwie wszelkie ważne dla jej okręgu zagadnienia, starała się omawiać je możliwie najzwięźlej, ograniczając również do minimum wszelkie tablice i zestawienia, których cyfry z konieczności nie sa, i nie mogą być jeszcze kompletne. Pewne kwestie, które dotychczas na tutejszym terenie nie nabrały ostrości, względnie układały się pomyślnie, jak np. zagadnienie podatkowe czy moment pracowniczy, łącznie z kwestią Rad zakładowych, pominięto na razie w ogóle, odkładając je do sprawozdania rocznego. Izba pragnęła dać obraz jej terenu działania w sposób możliwie wierny i bez wyjaskrawień. W każdym razie kończąc swe uwagi - Izba uważa za wskazane stwierdzić, że wszelkie ujemne czy przykre zjawiska gospodarcze na jej terenie miały charakter koniunkturalny - i że przy kontynuowaniu przezornej polityki ekonomicznej ogólny stan okręgu upoważnia na dalszą metę raczej do optymizmu.

Źródło: Archiwum Państwowe w Lublinie, Izba Przemysłowo-Handlowa w Lublinie, sygn. 63 , k. 1-41.

\section{BIBLIOGRAFIA:}

Dąbrowski K., Archiwalia izb przemysłowo-handlowych. Stan i perspektywy badań, pod red. idem, Ryki 2012, s. 28-44.

Dąbrowski K., Zarys historii Izby Przemystowo-Handlowej w Lublinie w latach 1929-1951, http://iph.lublin.pl/index.php/historia.

ABSTRACT:

The communist authorities in Poland had little social support, which was the reason why they had to activate the institutions and employees of the inter-war period in the process of bringing order to the socio-economic situation in the country. Chambers of Industry and Commerce of the Second Polish Republic were an important link between the authorities and entrepreneurs. In the changed reality they were a form of organization of private industry and trade. The authorities used these institutions to bring an end to the private sector in industry and commerce during the process of industry nationalization and the subsequent "battle of trade". The current document is an example of a periodical 
report prepared by the Chamber of Industry and Trade of Lublin, which sheds light on the first year after Germans were expelled from the Lublin region. It describes the process of reactivation of the Chamber and its subordination to the Polish Committee of National Liberation. It also addresses the issues of employment, prices, provision of supplies, effect of transportation difficulties on the process of normalization of economic activity and transfer of money. The second part characterizes the state of industry in the division of sectors, protection against machinery dismantling and transportation to Germany as well as features of post-war chaos. The final part analyses the specific nature of trade in the Lublin region, taking as its starting point the reflections on the inter-war period trade, mentioning main exported goods, characterizing sector structure and effects of war. The document also contains some reference to the insecurity blocking private initiative and fears against implementing the Russian model of trade.

Key words: chamber of industry and commerce, Lublin region, trade, industry

\section{NOTA O AUTORZE:}

Tomasz Osiński (ur. 1974) - historyk, doktor nauk humanistycznych, pracownik Oddziałowego Biura Edukacji Publicznej IPN w Lublinie. Zainteresowania badawcze: historia społeczno-gospodarcza ziem polskich w XIX i XX w. Autor scenariusza wystawy "Rewolucja społeczna" czy "dzika przebudowa". Przekształcenia własnościowe w Polsce w latach 1944-1956 i ich społeczne skutki (2014). Opublikował m.in.: Klika obszarnicza. Ziemianie w polityce personalnej Państwowych Nieruchomości Ziemskich (1946-1949), „Pamięć i Sprawiedliwość" 2(20)/2012; W oczekiwaniu na wywłaszczenie. Warunki życia i pracy w majatkach ziemskich na Lubelszczyźnie pomiędzy lipcem a październikiem 1944 roku [w:] Ziemiaństwo na Lubelszczyźnie, pod. red. H. Łaszkiewicza, t. V, Lublin 2012. 